\title{
EDUKASI FOOD PREPARATION YANG TEPAT DALAM MENGHADAPI ERA NEW NORMAL PANDEMI COVID-19 PADA KELOMPOK RUMAH TANGGA DI KELURAHAN BONTOMANAI, KEC. BONTOMARANNU, KAB. GOWA
}

\author{
${\text { Hasriani }{ }^{*}}^{*}$ \\ Sitti Arwati2 \\ Sitti Khadijah ${ }^{3}$ \\ $1^{*}, 2,3$ Program Studi Agribisnis, Fakultas Pertanian, Universitas Muhammadiyah Makassar, \\ Makassar, Indonesia \\ hasriani.ani@unismuh.ac.id ${ }^{1^{*}}$ \\ sittiarwati@unismuh.ac.id $\left.{ }^{2}\right)$ \\ khadijah@unismuh.ac.id ${ }^{3}$
}

Kata

Kunci: [new

normal,

food

preparation,

ketahanan

pangan]

Published by:

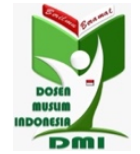

Abstrak: Pengabdian kepada masyarakat ini dilatarbelakangi oleh adanya upaya untuk memperpanjang umur simpan dari komoditas hasil pertanian agar dapat dikonsumsi dalam jangka waktu yang lebih lama dan membantu mengurangi sampah rumah tangga. Edukasi food preparation (persiapan bahan pangan) penting untuk dilakukan untuk membantu kelompok rumah tangga, dalam memenuhi kebutuhan pokoknya secara efektif dan efisien sesuai dengan kondisi new normal selama pandemi Covid-19 yang menganjurkan untuk lebih banyak melakukan kegiatan di rumah saja. Menjaga ketahanan pangan dapat dimulai dari tingkat rumah tangga dengan menerapkan food preparation. Tahapan sosialiasasi kegiatan ini dimulai pada bulan Mei 2021, dan pelaksanaan edukasi pada tanggal 17 Juli 2021. Pelaksanaan kegiatan edukasi food preparation bagi kelompok rumah tangga di Kelurahan Bontomanai Kecamatan Bontomarannu Kabupaten Gowa, terbagi menjadi beberapa tahapan: (1) sosialisasi kegiatan, (2) pelaksanaan kegiatan edukasi, (3) pendampingan dan pelatihan persiapan bahan pangan untuk food preparation, dan (4) monitoring dan evaluasi kegiatan. Metode yang digunakan pada kegiatan pengabdian ini yaitu edukasi dalam bentuk pendidikan dan pelatihan (ceramah, penayangan video dan demonstrasi). Pembagian food container masing-masing 20 pcs juga dilakukan agar kelompok rumah tangga di Kelurahan Bontomanai dapat langsung mempraktekkan pelaksanaan food preparation ketika pulang ke rumah masing-masing. Pendampingan setelah kegiatan pendidikan dan pelatihan merupakan kegiatan lanjutan untuk memantau apakah materi yang diberikan dapat diterapkan oleh mitra sasaran dengan baik. Hasil pengabdian masyarakat ini yaitu mitra kelompok rumah tangga sudah memahami dan melakukan food preparation secara mandiri.

Copyright (C) 2022 The Author(s)

This article is licensed under CC BY 4.0 License

(cc) $\mathrm{EY}$

https://dmi-journals.org/jai/ 


\section{Pendahuluan}

Pandemi covid-19 yang telah terjadi selama lebih dari satu tahun, menimbulkan dampak yang cukup besar pada berbagai sektor, salah satunya pada sektor pertanian. Dikutip dari Pusat Penelitian dan Pengembangan Perkebunan 27/05/2020, mengatakan bahwa ada 6 dampak yang mempengaruhi sektor pertanian yaitu; (1) harga pasar dan pertanian yang kemungkinan meningkat karena adanya pembatasan pergeragakan masyarakat yang akan mempengaruhi stabilitas supply and demand; (2) rantai pasok pangan menjadi lambat dan kekurangan; (3) kesehatan petani yang menurut Sensus Penduduk 2017 berada pada usia renta (hampir 58 tahun) dan rawan terkena virus Covid-19; (4) tenaga kerja pertanian juga akan terinfeksi; (5) keselamatan kerja dan penggunaan alat pelindung diri, khususnya untuk peternak yang rentan terkontaminasi langsung dengan kotoran hewan; dan (6) kerusakan sumber daya pangan khususnya sayuran dan buah-buahan yang memiliki kadar air tinggi sehingga mudah membusuk dan rentan terpapar virus Covid-19.

Pada era new normal, masyarakat dihadapkan dengan keadaan yang serba terbatas baik pergerakan keluar rumah maupun interaksi antar individu. Pembatasan ini akan menyebabkan masyarakat lebih memikirkan bagaimana cara mempersiapkan bahan pangan untuk konsumsi sehari-hari tanpa harus berbalanja bahan pangan tersebut setiap hari. Hal ini akan berdampak terhadap supply demand bahan pangan itu sendiri, dan tentunya akan turut dirasakan juga oleh petani sebagai produsen penyedia bahan pangan. Kondisi ini akan menyebabkan terjadinya penumpukan bahan pangan di tingkat rumah tangga. Di sisi lain, penumpukan bahan pangan tanpa penanganan dan penyimpanan yang tepat juga akan mempercepat kerusakan dari bahan pangan itu sendiri baik kerusakan biologis dan mikrobiologis, kerusakan fisik, maupun kerusakan kimiawi. Hal ini sesuai dengan pendapat Koeswardhani (2020) bahwa pada suhu ruang $\left(27^{\circ} \mathrm{C}\right)$, daging, ikan, dan unggas menjadi busuk dalam 1-2 hari. Hal ini juga akan terjadi pada beberapa jenis buah-buahan dan sayuran daun, seperti juga pada susu mentah dan bahan pangan segar lainnya. Pada suhu ruang atau suhu lapangan, beberapa bahan pangan bahkan dapat menjadi tidak berharga (rusak, busuk) dalam beberapa jam.

Kelurahan Bontomanai merupakan salah satu dari 9 kelurahan yang ada di Kecamatan Bontomarannu Kabupaten Gowa Provinsi Sulawesi Selatan dengan jumlah penduduk 4.844 jiwa dan tingkat kepadatan penduduk sebesar 765 jima/ $\mathrm{km}^{2}$ (BPS Kabupaten Gowa, 2018). Kepadatan jumlah penduduk ini menjadi salah satu indokator yang menandakan bahwa dibutuhkan ketersediaan bahan pangan yang cukup besar untuk dapat mencukupkan seluruh kebutuhan pokok penduduk. Mitra pada kegiatan pengabdian ini adalah kelompok rumah tangga di Kelurahan Bontomanai yang terdiri dari wanita yang telah berkeluarga, kegiatan kesehariannya adalah mengurus rumah tangga dan tidak memiliki pekerjaan lainnya. Mitra memiliki aktifitas sehari-hari yang lebih banyak berinteraksi dengan penyediaan bahan pangan untuk konsumsi rumah tangga.

Kondisi seperti ini yang menyebabkan diperlukannya solusi penanganan bahan pangan yang praktis untuk diterapkan pada mitra sasaran dan tentunya membantu mengurangi frekuensi keluar rumah. Food preparation (persiapan bahan pangan) adalah cara menyimpan bahan pangan, baik mentah, setengah matang, maupun matang dalam lemari pendingin untuk digunakan dalam jangka waktu tiga hari sampai sebulan (Pramitasari, 2020). Food prep mengandalkan penggunaan kontainer dengan tutup 
kedap udara untuk menyimpangan bahan pangan. Food prep tidak hanya dilakukan untuk mengawetkan bahan pangan selama penyimpananan, tetap juga dapat menghemat waktu saat akan memasak karena persiapan hanya dilakukan pada awal periode ketika selesai berbelanja kebutuhan bahan pangan. Oleh karena itu, kegiatan PKM ini mengambil sampel kelompok rumah tangga yang dianggap sebagai fokus bagi kegiatan edukasi food preparation yang akan dilakukan. Kegiatan PKM ini tidak terbatas pada edukasi saja, tetapi juga kegiatan pendampingan agar mitra sasasaran dapat menerapkan food preparation secara konsisten selama era new normal atau sampai pandemi Covid-19 selesai. Selain itu, kegiatan ini diharapkan dapat membantu agar bahan pangan tidak banyak yang terbuang percuma dan berujung di tempat sampah.

\section{Metode Pelaksanaan}

Kegiatan pengabdian kepada masyarakat ini dibagi menjadi beberapa tahapan yaitu sebagai berikut :

1. Sosialisasi kegiatan

Merupakan tahapan awal yang diperlukan agar kegiatan pengabdian kepada masyarakat ini dapat terlaksana dengan baik. Tahapan ini bertujuan untuk mengetahui kondisi mitra dan lingkungan sekitar, sekaligus sosialisasi kegiatan yang akan dilakukan. Sosialisasi dimulai pada bulan Mei 2021 disertai observasi di lokasi mitra yaitu di Kelurahan Bontomanai, Kecamatan Bontomarannu, Kabupaten Gowa.

Sosialisasi juga dilakukan untuk menggali informasi sebanyak-banyaknya, juga membahas mengenai penerapan food preparation oleh masyarakat apakah sebelumnya telah dilakukan atau tidak, ataupun persoalan lainnya yang berkaitan dengan perubahan sosial dan budaya di masyarakat akibat adanya penerapan protokol kesehatan di era new normal.

2. Pelaksanaan edukasi

Tujuan dari kegiatan pengabdian ini yaitu untuk memberikan edukasi kepada kelompok rumah tangga mengenai food preparation. Untuk mencapai tujuan tersebut maka metode yang akan digunakan yaitu ceramah, pemutaran video, dan demonstrasi. Ceramah dilakukan untuk mengedukasi masyarakat secara verbal yang dikombinasikan dengan pemutaran video mengenai kegiatan food preparation oleh beberapa influencer. Pada kegiatan demonstrasi, mitra sasaran akan diajarkan mengenai penanganan pasca panen sederhana untuk bahan pangan pada tingkatan rumah tangga, meliputi sortasi dan pembersihan, pengelompokan untuk bahan pangan yang akan disimpan pada food container dan yang disimpan pada kondisi terbuka.

3. Pendampingan dan pelatihan persiapan bahan pangan untuk food preparation

Adapun prosedur dalam pelaksanaan food preparation tersebut adalah sebagai berikut :

a. Merencanakan menu makanan untuk seminggu.

Dilakukan agar dapat diketahui berapa banyak bahan pangan yang akan dibeli ketika berbelanja ke pasar. Menu makanan seminggu sudah termasuk hitungan masak sebanyak tiga kali dalam satu hari.

b. Persiapan alat dan bahan

Peralatan yang dibutuhkan yaitu pisau, talenan, lap bersih, baskom, dan food container yang aman untuk makanan (food grade). Bahan pangan disesuaikan dengan perencanaan menu makanan sebelumnya. 
c. Sortasi dan Pembersihan

Dilakukan untuk memisahkan antara bahan pangan yang lebih mudah rusak dan tidak, seperti sayuran dan daging-dagingan. Setelah sortasi, dilakukan pembersihan sesuai karakteristik bahannya,

d. Pengelompokan untuk penyimpanan bahan pangan

Dilakukan untuk menghindari terjadinya kontaminasi silang yang menyebabkan bahan lainnya menjadi busuk. Pengelompokan dilakukan baik untuk sayuran daun, sayuran umbi, daging, bumbu dapur maupun rempah. Setelah itu, dilakukan penyimpanan ke dalam food container lalu dimasukkan ke dalam lemari pendingin. Beberapa bahan pangan yang memiliki kadar air tinggi seperti sayuran daun, sebaiknya diberi tissue dapur pada bagian dasar food container sebelum diisi bahan pangan. Hal ini dilakukan untuk membantu menyerap kadar air yang ada dan menghambat proses pelayuan dan pembusukan.

4. Monitoring dan evaluasi kegiatan

Dilakukan setiap akhir bulan terhadap seluruh solusi kegiatan yang dilakukan. Hasil monitoring dan evaluasi dijadikan sebagai landasan kerja dalam menyelesaikan permasalah mitra. Pada akhir dari target pelaksanaan kegiatan PKM, maka tim menyusun laporan akhir sebagai bentuk pertanggung jawaban kepada LP3M bahwa kegiatan PKM telah dilaksanakan sesuai dengan prosedur sebagai mana mestinya.

\section{Hasil dan Pembahasan}

Pelaksanaan kegiatan Pengabdian Kepada Masyarakat (PKM) mengenai edukasi food preparation (persiapan bahan pangan) yang tepat dalam menghadapi era new normal pandemi Covid-19 ini dimulai pada bulan Mei 2021 dengan melakukan sosialisasi dengan mitra sasaran mengenai program yang akan dijalankan, target dan luaran yang akan dihasilkan. Kegiatan utama dari PKM ini lebih banyak berupa edukasi dan penyuluhan kepada mitra dalam hal ini kelompok rumah tangga. Kegiatan edukasi tersebut dilakukan selama 1 hari yaitu pada hari Sabtu tanggal 17 Juli 2021.

1. Edukasi Metode Food Preparation

Era new normal semenjak pandemi covid-19 satu tahun terakhir, menyebabkan pergerakan manusia menjadi terbatas dan diikuti aturan pemerintah untuk melaksanakan protokol kesehatan yang ketat. Salah satunya yakni kegiatan berbelanja kebutuhan pokok di pasar, yang biasanya dapat dilakukan setiap hari, saat ini hanya dapat dilakukan sekali dalam 4-7 hari. Hal ini juga menyebabkan penumpukan bahan pangan di tingkat rumah tangga yang imbasnya akan menambah jumlah sampah rumah tangga karena banyaknya bahan pangan yang membusuk sebelum diolah.

Kegiatan ini dilakukan pada tanggal 17 Juli 2021 dan difokuskan di rumah mitra (yang terletak di Lorong Lempangan, Kelurahan Bontomanai. Edukasi ini melibatkan pemateri dari pelaksana pengabdian itu sendiri. Pokok materi yang diberikan berkaitan mengenai pengenalan food preparation yang dapat diterapkan untuk kelompok rumah tangga dalam mengurangi intensitas keluar rumah, menghemat uang belanja, mempersingkat waktu memasak, serta membantu mengurangi sampah pertanian. Dalam kegiatan ini juga diperkenalkan food container sebagai peralatan yang digunakan dalam food preparation. Mitra kelompok rumah tangga terdiri dari 25 orang yang memang masih awam dalam melaksanakan food preparation. Mereka terbiasa berbelanja dan menyiapkan bahan makanan untuk keperluan makan sehari, dan harus berbelanja lagi untuk kebutuhan 
esok harinya. Dari pemaparan materi yang diberikan, mitra masih kesulitan dalam mengidentifikasi bahan pangan dan penangangan pasca panennya serta yang dapat disimpan dalam kondisi berbeda. Oleh karena itu kegiatan ini akan ditindaklanjuti dengan kegiatan pelatihan dan pendampingan sampai mitra dapat melaksanakan food prepration secara mandiri di rumah masing-masing.

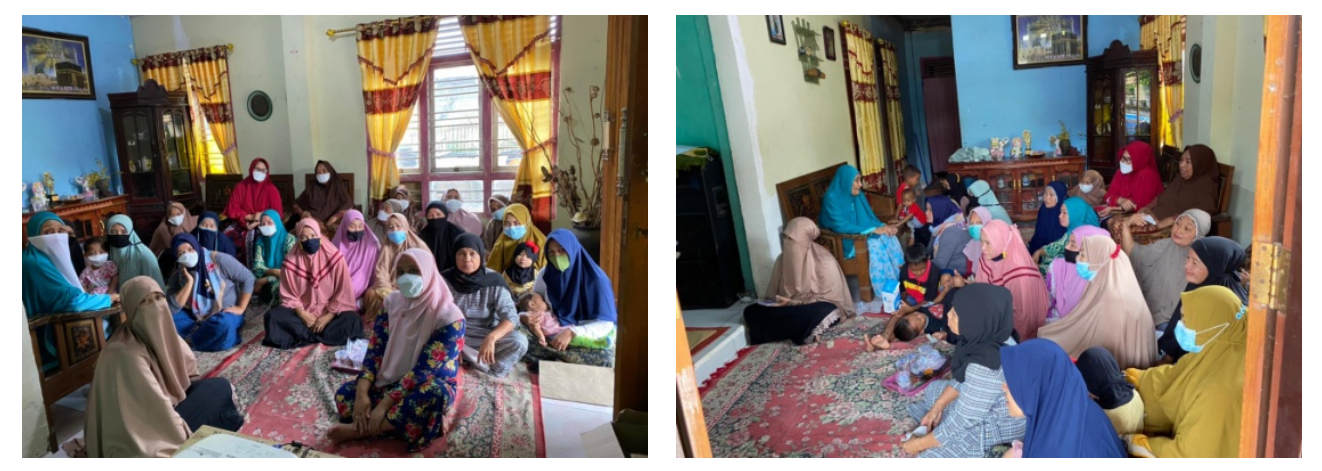

Gambar 1. Sosialisasi dan Edukasi Metode Food Preparation

2. Pelatihan Pelaksanaan Metode Food Preparation

Sebagai kelanjutan kegiatan sosialisasi dan edukasi sebelumnya, maka mitra kelompok rumah tangga didampingi untuk dapat melaksanakan metode food preparation secara mandiri. Materi pelatihan yang dilakukan meliputi (1) pengenalan alat dan bahan dalam pelaksanaan food preparation, (2) identifikasi karateristik bahan pangan, (3) perbedaan metode penyimpanan berbagai jenis bahan pangan, dan (4) masa simpan bahan pangan melalui metode food preparation.

Pelatihan dalam bentuk edukasi dan penyuluhan ini dilakukan sebagai upaya pemberdayaan perempuan yang dicirikan sebagai "jantung" dari rumah tangga, yang mengatur segala kebutuhan sandang dan papan untuk dirinya dan anggota keluarganya. Pemberdayaan ini bertujuan untuk merubah pola pikir dan meningkatkan keterampilan perempuan dalam hal ini kelompok rumah tangga mengenai persiapan bahan pangan yang awalnya dilakukan kurang praktis menjadi lebih efektif dan efisien dengan menerapkan food preparation. Hal ini sesuai dengan pendapatan Mardikanto (1999) bahwa pemberdayaan dapat dilakukan dengan cara penyuluhan, salah satu maksud dari penyuluhan yaitu merubah masyarakat menjadi memiliki pengetahuan dan keterampilan.

Alat utama yang digunakan dalam food preparation yaitu food container yang merupakan wadah plastik dan dapat digunakan berulang kali. Keunggulan dari penggunaan food container yaitu adanya tutup dari wadah yang memberikan suasana kedap udara bagi bahan pangan jika disimpan di dalamnya. Kondisi ini yang akan membantu memperlambat proses pembusukan dan mempertahankan mutu bahan pangan sampai 5-7 hari selama penyimpanan dalam lemari pendingin. Penggunaan tissue dapur sebagai bahan juga membantu menyerap kadar air yang berlebihan dari bahan pangan yang memang memiliki karakteristik kadar air yang tinggi. Materi disampaikan dengan santai secara lesehan dan tetap memperhatikan protokol kesehatan dan menerapkan metode interaktif yang diisi dengan banyak tanya jawab. 

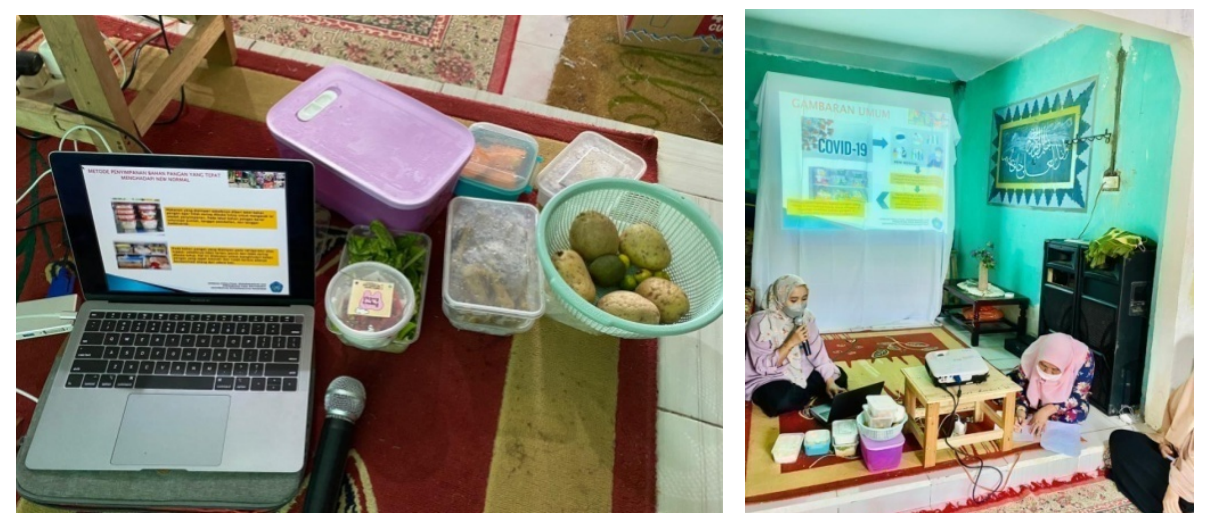

Gambar 2. Pelatihan Pelaksanaan Food Preparation

\section{Pemberian Food Container}

Diakhir sesi edukasi food preparation, dilakukan penyerahan food container secara simbolis kepada mitra. Food container ini diharapkan dapat menjadi wadah awal bagi mitra dalam menerapkan food preparation secara mandiri. Food container terdiri dari beberapa ukuran (500-1000 ml), berbahan plastik poli propilen yang food grade (aman untuk makanan), tahan panas (microwave) dan dapat digunakan berulang kali tanpa resiko bereaksi dengan bahan makanan.

Food container dengan bahan plastik poli propilen memiliki permeabilitas uap air, gas, dan bau yang rendah sehingga bahan pangan yang dikemas dan disimpan di dalamnya dapat lebih awet dan terhindar dari kontaminasi silang dengan bahan pangan lainnya selama food container tersebut dalam kondisi tertutup rapat. Apalagi kegiatan food preparation ini mayoritas menerapkan metode penyimpanan dalam lemari pendingin (suhu refrigerator). Hal ini sejalan dengan penelitian yang dilakukan oleh Mareta dan Sofia (2011) bahwa permeabilitas plastik propilen lebih kecil dibandingkan plastik polietilen sehingga uap air akan lebih sulit menembus plastic propilen daripada polietilen.

Food preparation dengan menggunakan kemasan yang tepat akan mempengaruhi waktu simpan dari bahan pangan. Food container dengan bahan plastik yang sesuai (food grade dan permeabilitas rendah) tentu memberikan pengaruh yang berbeda dibandingkan menggunakan wadah plastik dengan bahan lainnya. Bahan pangan yang memiliki kadar air tinggi seperti sayuran, bukan tidak mungkin selama penyimpanan akan mengalami penurunan kadar air sehingga ketika akan dikonsumsi sudah dalah kondisi layu (tidak segar). Penggunaan food container dapat menghambat keluarnya kadar air secara berlebihan oleh bahan pangan. Hal ini sesuai dengan penelitian Latifah (2010) bahwa selama penyimpanan seharusnya terjadi peningkatan kadar air, tetapi pada kondisi tertentu dapat mengalami penurunan. Hal ini bisa terjadi karena adanya peningkatan suhu dan adanya penurunan kelembaban sehingga menyebabkan perpindahan uap air dan bahan ke lingkungan, akhirnya kadar air pada bahan menurun. 

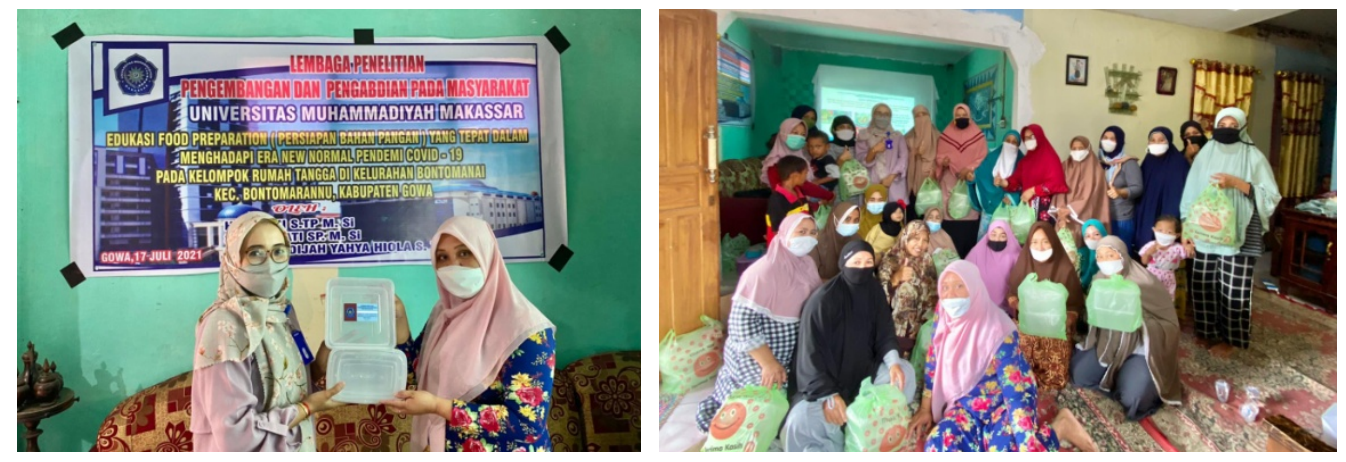

Gambar 3. Penyerahan Food Container

\section{Kesimpulan}

Kegiatan pengabdian kepada masyarakat berupa edukasi food preparation (persiapan bahan pangan) yang tepat dalam menghadapi new normal era pandemic Covid-19 bagi kelompok rumah tangga di Kelurahan Bontomanai, Kecamatan Bontomarannu, Kabupaten Gowa dapat disimpulkan bahwa mitra kelompok rumah tangga dapat memahami dan melaksanakan food preparation secara mandiri. Pendampingan dan pelatihan yang diberikan serta pemberian food container sebagai salah satu alat dalam melaksanakan food preparation, membantu mitra dalam menerapkan ilmu yang telah diberikan dalam kegiatan PKM.

Hasil rekomendasi pada kegiatan pengabdian kepada masyarakat ini, mitra sebaiknya menjaga konsistensi dalam penerapan food preparation agar dapat membantu pemerintah dalam pelaksanaan protokol kesehatan di era new normal pandemi Covid19, karena tidak perlu lagi untuk keluar rumah dan berbelanja bahan pangan setiap hari. Pemerintah Kelurahan Bontomanai sebaiknya lebih menekankan kepada masyarakat dalam menaati aturan protokol kesehatan utamanya ketika berbelanja di Pasar Sentral yang sering menimbulkan kerumunan ketika pasar beroperasi.

\section{Ucapan Terimakasih}

Ucapan terima kasih kami sampaikan kepada Lembaga Penelitian dan Pengabdian Kepada Masyarakat (LP3M) Universitas Muhammadiyah Makassar atas kerjasamanya dalam pelaksanaan kegiatan Pengabdian Kepada Masyarakat untuk tahun anggaran 2021.

\section{Referensi}

BB Pascpanen. Balai Besar Penelitian dan Pengembangan Paascapanen Pertanian. 2020. Buku Saku Bahan Pangan Potensial Anti Virus dan Imun Booster. Bogor (ID) : Balai Besar Penelitian dan Pengembangan Pascapanen Pertanian.

Koeswardhani, 2021. Dasar-Dasar Teknologi Pengolahan Pangan. http://www.repository.ut.ac.id. (April 2021)

Latifah. N.H. 2010. Pemilihan Jenis Plastik dan Pembuatan Desain Kemasan untuk Keripik Tette Madura. Skripsi. Bangkalan : Teknologi Industri Pertanian Fakultas Pertanian Universitas Trunojoyo Madura. 
Lembito H.2020. Dampak Ekonomi Penyebaran Covid-19 terhadapat Kinerja Sektor Pertanian. Bul Perenc Pembang Pertan. 1(2):6-17.

Mardikanto, Totok. 1999. Penyuluhan Pembangunan Pertanian. Surakarta : Sebelas Maret University.

Mareta, D.T dan S. Nur. A. 2011. Pengemasan Produk Sayuran dengan Bahan Kemas Plastik Pada Penyimpanan Suhu Ruang dan Suhu Dingin. Jurnal Mediagro. Vol.7 No.1 Hal 26-40.

Pramitasari, Rianita, 2020. Cara Mudah Menyiapkan Bahan Pangan Tetap Segar \& Tahan Lama Saat Pandemi Covid-19. 